THE EASTERN BELTED KINGFISHER, MEGACERYLE ALCYON ALCYON (LINNAEUS), IN RELATION TO FISH MANAGEMENT ${ }^{1}$

\author{
J. Clark Salyer, II \\ U. S. Department of the Interior, Fish and Wildlife Service, \\ Washington, D. C. \\ AND \\ KarL F. Lagler \\ Department of Zoology, University of Michigan, \\ Ann Arbor, Michigan
}

\begin{abstract}
The kingfisher is the most common and universally distributed bird predator of fish in Michigan. Its principal migration routes are along the Great Lakes shores. Nesting territories are established along streams and lake shores; they are usually larger in the former than in the latter. The kingfisher is diurnal in its feeding with three peaks of activity-morning, afternoon, and early evening. First feeding of fledgelings is on insects; this food is followed by crayfish, then by fish. Fish eaten average about 2.3 inches in length and at fish hatcheries are mostly the species being propagated. On natural waters the food consists mostly of non-food and non-game fisbes and crayfish. Predation pressure varies with season and within season according to weather, nest distribution, and environmental suitabliity of waters for feeding activity. Because of their feeding proclivities, it is undesirable to have kingfishers about fish hatcheries and rearing stations. At present, general control on natural waters is not biologically justified.
\end{abstract}

\title{
INTRODUCTION
}

This report is one of a series dealing with the relationships between fish predators and fish production. The purpose of this particular study has been to determine the relation between the eastern belted kingfisher and the production, artificial or natural, of food, game, and forage fishes. It has thus been necessary to determine the nature and extent of fish predation by this bird on natural waters and at outdoor fish hatcheries and rearing stations. As it became increasingly apparent that substantial losses of highly valued fish could result from the feeding activities of this predator at such stations, non-lethal controls were designed and tried (Lagler, 1939).

Our data are of two kinds: field observations of habits of kingfishers and the nature of fish populations; laboratory analyses of stomach contents. One or the other of the authors has devoted some time to this

\footnotetext{
1 Contribution from the Department of Zoology of the University of Michigan, and from the Institute for Fisheries Research of the Michigan Department of Conservation. Substantial financial ald was given this study by the Wildlife Management Institute (Amerjean Wildlife Institute) and by the Assoclated Fishing Tackle Manufacturers.
} 
study each year from 1930 to 1945 and field observations and collections have been made in Michigan during all months.

Most of the birds used for food analyses from fish-cultural establishments were obtained by employees of the Michigan Department of Conservation who followed instructions issued by us for the care and preservation of this material. Many other individuals, including colleagues in the Institute for Fisheries Research, collected specimens for us from natural waters.

We extend our sincere gratitude to the many persons and agencies that have helped us. Special thanks are due to Carl L. Hubbs, Fred A. Westerman, A. S. Hazzard, J. W. Leonard, and Karl E. Goellner. Ralph Hile read the manuscript and offered many critical suggestions for its improvement.

\section{Field Otbsizkvations}

Since the emphasis of this paper is on the relationship of the food habits of the kingfisher to practical fishery management, we are presenting no lengthy discussion of life history which has been summarized by Bent (1940). Included only are apparently new materials based upon actual field observations and certain detailed information which will supply greater detail on activities of the bird which are generalized in other, previous accounts. Salyer is responsible for the field observations and their interpretation in the sections on distribution and migration, mating and nesting, and populations. Of all the observations recorded in the past on this species, those made by Gould ${ }^{2}$ appear to be the most accurate. In fact, this painstaking study well merits publication even at this late date (vide Lagler, 1943).

Distribution and Migration.-Of all the winged fish predators of Michigan waters, the kingfisher is probably the most widely distributed. The species is principally a summer resident in Michigan but occasional individuals may be seen all winter long. The fact that this is a peninsular state with most of its boundaries on the shores of the Great Lakes has a profound influence on the migration and distribution of the kingfisher in the region. The first thing that strikes the observer who works daily in the field throughout the spring and summer months is the fact that travel is not haphazard or "cross-country" as stated by many writers. In short, in both the Upper and Lower Peninsulas, the shores of the Great Lakes are basic migration highways for the birds' movement.

Kingfishers pass up the shores of the Great Lakes in almost the same manner and regularity that native hawks exhibit in their migrations. On April 12, 1931, Salyer observed individual kingfishers moving along the west shore of Lake Huron north of the city of Port Huron at the rate of about 15 per hour during a 4-hour period in the morning. In the fall of the same year he found kingfishers moving southward on the

${ }^{2}$ Gould, Victor Eugene. 1934. "A monograph of the belted kingfisher Megaceryle alcyon (Linnieus)", 311 pages plus illustrations, summary, and bibliography. Typewritten. 
shores of Lake Michigan at the mouth of the Pentwater River at the rate of 12 per hour. This observation was made on October 25; previous to this date Salyer had spent 3 days on the headwaters of the Pere Marquette River and had seen only one kingfisher there. It seems to the observer that on spring migration, kingfishers move along the Great Lakes shores and turn up major river valleys which they folow, dropping off as they locate, or return to, both new and old nesting sites.

Mating and Nesting.-The female is slightly the larger, usually weighing a little more than 6 ounces, whereas the male averages a little less than 6 ounces. Observations by Salyer indicate that the female is the more aggressive of a nesting pair and takes the initiative in selecting the nesting territory. On the Huron River in Washtenaw County, the Platte River in Benzie County, and the Little Manistee River in Lake County, females have been found activly defending sites prior to getting a mate.

A mated pair of birds not only has a definite nesting territory, which they defend against all other individuals with fury and persistence, but their territory can be marked almost to the exact yard by the observer because of the behavior of the birds, described below.

A great amount of time in early mating season is spent by the mated pair in traversing and defending their territory. During the daylight hours at least, most of the territory appears to be patrolled at intervals of 10 to 15 minutes. All larger animals, including man, cats, dogs, and larger birds are circled and scolded and of ten followed through the area. Invaders of the same species are violently set upon forthwith.

The size of the nesting territories located on lakes contrasts sharply with that of sites on most streams or rivers. On lakes the longest territorial selection found was $1 \frac{1}{2}$ miles of shore, but the average comprises about $1 / 2$ mile. This $11 / 2$-mile territory was occupied by a nesting pair of kingfishers on Black Lake, Cheboygan County, in June and July 1931. On the other hand, two nesting pairs used about $1 / 2$ mile each of shoreline on Pleasant Lake, Washtenaw County, in May 1931. Another pair, during the same period, selected about $1 / 2$ mile of shoreline of Portage Lake, Livingston and Washtenaw Counties, which included an extensive cottage area. The stretch of shoreline selected invariably includes all or a portion of a small sheltered bay which provides a reasonable extent of unruffled feeding surface regardless of most directions of the wind. Our studies indicate that exposure to wind action, especially on the lake habitat of the species, is almost as important as turbidity in determining the distribution of the population and the location and success of feeding. In this respect, it is significant to note that there are more kingfishers per unit of shoreline on the smaller Michigan lakes than upon such large, rough bodies of water as Houghton, Hubbard, and Mullet Lakes.

Limitations of feeding area on rivers by vegetative cover, deep and unfishable pools, and fast currents which reduce visibility, apparently require the birds to establish much larger territories. Thus, the usual range is most likely to be from $1 \frac{1 / 2}{2}$ to 3 miles or more. In May and June 
1931, Salyer kept under close observation a pair of birds known to dominate the headwater country of the Little Manistee River for a distance of 6 miles. Although these birds were not marked, they appeared to be the only pair of kingfishers along this entire stretch of river. Their nesting hole was found and the feeding habits both of the adults and the young after leaving the nest were followed daily. Here the extensive "brushing-over" of long sections of the stream and the fast current seemed to limit feeding opportuniti:s.

On the lower reaches of some of Michigan's larger rivers which are ordinarily quite turbid, the bird is an infrequent nester; however, all adjacent sloughs and backwater areas with relatively clear water have their nesting birds so that the nesting population of the entire state is of a somewhat uniform density.

In May 1931 Salyer made some interesting observations on a female bird which had selected a territory on a Huron River cutoff a few miles southeast of Ann Arbor, Michigan. This female actively defended the region for 2 days and took a mate on the afternoon of the second day. By the morning of the third day the male bird seemed to become familiar with the territory originally defended by the female. This male (K-318) was collected at 9:00 a.m. on the third day but by 3:00 p.m. on the same day there had appeared a new male bird which also learned the territory in a short time. The territory was composed of two small ponded areas estimated over-all at about 35 acres of water and marsh.

During the early mating season it is common to see and hear male kingfishers flying at altitudes of about 300 feet up this river valley. At regular intervals the migrant gives his characteristic rattling call. If a determined and vigorous challenge is returned by a prior occupant from below, he frequently passes on without stopping. Failing to get a challenge, the bird is often seen to go into a spectacular aerial dive and fly at a lower level. Sometimes he meets a female; if she already has a mate, she drives him away but if not, she may accept him. In any given watershed there always seem to be one or two bachelor birds which have not mated and which give the mated pairs considerable concern, especially in the early morning hours, as evidenced by repeated observations followed by collections.

Feeding Habits.-As is generally known, the kingfisher is a very adept fisherman, but its fishing is confined to those individuals of its prey near the surface or in shoal water. It apparently prefers to feed in the shallow waters of streams or lakes. In lotic habitats, fishing success is not as good in deep pools as it is in shallower reaches having a moderate to slow current.

The kingfisher is strictly a diurnal bird; it speedily retires with the advent of twilight in the evening. On the other hand, it is an early bird on the stream, becoming active in the early light before sunrise. The first hour of daylight is spent in feeding and repeatedly patrolling the territory during the nesting period. 
Peaks of feeding activity occur in the morning, afternoon, and evening. Stomachs of birds taken very early in the morning prior to 7:00 a.m. are most often quite empty or contain a single recently taken item. Full stomachs are found more frequently in birds collected from 7:00 to 10:30 a.m. From about 11:00 a.m. to 2:30 p.m. apparently is largely a non-feeding period, with stomachs collected between 2:30 and 4:30 p.m. again being relatively full. Stomachs taken from around 4:30 to $6: 30$ p.m. generally show bone remains and seemingly the birds make their final feeding of the day just prior to dusk.

The first food which the young get when they leave the nest and start feeding without parental aid is insects, particularly mayflies. They are very fat when they first fly; this good condition is apparently necessary because the parents give the young birds little food just prior to the dcparture, parhaps to compel them to begin seeking food for themselves. Several broods have been watched by Salyer throughout the first and second weeks of their lives after they left their nests. In general, the family remains together for 10 to 15 days. During the first 3 or 4 days the young catch only flying insects from advantageous perches near the water, the parents generally perch on dead trees or exposed branches and the young on nearby dogwood, alder, or other shrubs where they are somewhat hidden. From these protected vantage points they fly out and seize a passing mayfly or caddisfly in a characteristic fly-catcher manner. All of the young of a brood taken on July 4, 1941, on the Black River (Montmorency County) on their first day on wing were feeding on insects. Several other broods and individual young showed the same habit. The young can be readily identified as such by their tarsal nesting callosities which gradually disappear toward the end of the third week on the wing (determined by field collections of birds of known age by Salyer).

During this period the young can be approached and observed quite closely despite the frantic warnings of the parents. The cries of the parents seem to rally the flock together and to keep it concentrated generally within a 100-yard stretch along the margin of the water area. It is most amusing to see both cedar waxwings and young kingfishers feeding on flying insects along northern trout streams in an almost identical manner.

After learning to catch insects, the young devote the fifth to tenth day on the wing almost exclusively to learning to capture crayfish. Broods in this period show a striking uniformity of behavior. For example, J. R. Greeley collected practically all of a brood on the Big South Branch of the Pere Marquette River (in Mason and Newaygo Counties) in the period from July 23 to July 28, 1931. All of these birds were feeding wholly on Cambarus. Again, Greeley collected a brood of young on August 14, 1931, on the same stream, of which all had fed upon crayfish while the male parent, also collected, was feeding normally upon fish; its stomach contained a 4 -inch redhorse (Moxostoma sp.). This transitional crayfish-eating habit is substantiated by the stomach contents of individual 
young birds from several other points throughout the state. Thus, the kingfisher does not ordinarily begin to catch fish until the latter part of its second week on the wing. Two juvenile males and a juvenile female, collected at 7:30 a.m. on June 25,1931 , all had caught trout; they were then 18 days on the wing.

During the latter portion of the crayfish-feeding period, the family group is not as closely knit as previously and gradually disperses; the parents finally disappear and the young expand their feeding areas. The young, however, continue for a time to feed in the same general region in which their nest was located. They are usually found feeding first at intervals of $1 / 4$ to $1 / 2$ mile from the nesting site and at greater distances in late August and September.

The writers have not spent much time studying the life of the kingfisher in the nest as this has been well covered by other authors. It was obvious, however, from the observations we made, that we could not accurately assay the food of nestlings by examining remains in the nests since females were repeatedly seen during the day to carry off a bolus or pellet of waste or undigested food remains from the nest. Because of the great quantities of food required daily to sustain the nestlings, the parents must, of necessity, remove the waste or the nest soon would become so congested with this material as to leave no room for either adults or young. We have not substantiated the observations of White (1939) that the young digest bones totally whereas the adults regurgitate the heavier bone material. It appears to us rather that in the initial period of feeding the nestlings, the parents present them with smaller and more delicate fish which disintegrate easily . Adults seem capable of digesting bone for in the stomachs we have examined both partially dissolved as well as fragmented bone have appeared. Thus, we hold, there is evidence of erosion and absorption in contradiction to the findings of White (1939).

It is our opinion that digestion in a kingfisher takes place more rapidly than in any other of the bird predators of Michigan fishes. The stomachs of kingfishers shot by us while they were feeding in their natural habitat are almost invariably either full of largely undigested food or contain only the traces of the last meal. One does not often get intermediate stages of digestion as in the case of the herons of which we have examined many specimens.

The total length of all fish eaten by kingfishers in Michigan averages less than 3 inches and ranges from 1 to 7 inches (Table 1 ). The minimum and maximum lengths were encountered only once each in the 729 specimens for which actual measurements or estimates based on comparative material were available. Most of the lengths determined were less than 5 inches; it is likely that fish of greater length are swallowed with difficulty. Individuals have been seen carrying fish in the 6- to 7-inch size group and sometimes have been observed to drop or abandon them. Fish which are intentionally or accidentally dropped by kingfishers show distintive marks on each side from the pincer action of the bill (as also 
noted by White, 1936). Often these marks are numerous on larger fish and bear evidence of manipulation in the unsuccessful effort to hold or swallow; we have several trout about 6 inches long in our collection which have these marks. The typical habit of attack and subsequent ingestion is for the bird to grasp a prey fish, forceps-fashion, with a lightning-like thrust aimed a little ahead of the middle of the body, fly to a perch, gradually turn the fish, and swallow it head first. Crayfish are taken similarly but are turned to pass down the esophagus tail first. Most of the whole or nearly whole fish and crayfish taken from stomach or esophagus are found headed in the directions indicated and are marked as described. The kingfisher does not spear or puncture larger prey with the closed bill as the great blue heron frequently does.

The kingfisher has been accused of taking nestling birds; we have never seen this nor do our food analyses give evidence of it.

Populations.-In the opinion of Salyer, the abundance of kingfishers on Michigan trout streams appears to parallel the striking increase of beaver population of the state in the decade prior to 1934. Beaver ponds opened up long reaches of the streams previously sheltered from kingfisher activilies by overhanging trees and shrubs. There was a steady increment in the kingfisher population per stream unit on the Gladwin Game Refuge, which grew in proportion to the increased area flooded by the activities of the ever growing beaver population. In the summer of 1931 there was apparently only one kingfisher on 6 miles of the Jordan River (Charlevoix and Antrim Counties). In 1934, when Salyer was working in the same region again on beaver-trout investigations, 15 kingfishers were found in the same stretch of stream.

The relative richness of individual water courses also has a direct bearing on the number of kingfishers and other fish predators. For example, the Big South Branch of the Pere Marquette had by far a larger population of predatory birds, including kingfishers, than did the main stream. J. R. Greeley, in making a 14-mile float of 7 hours' duration down the Big South Branch, saw at least 12 individual kingfishers. Such rich streams as the Platte River (Benzie County) have a relatively heavy population of kingfishers in comparison with a poorer stream such as the Boardman River (Grand Traverse County). Such contrasts are repeated many times over the state. For the suitable portions of the Northeast Margaree and its tributaries in Nova Scotia, White (1936) estimated one kingfisher nest per mile with a minimum of seven birds ultimately feeding from each nest.

Predation Pressure.-Predation by kingfishers on natural waters is different in quality and quantity in the different ecological situations represented in the state and it varies in all situations with the weather and seasons. The pressure reaches its low during winter months when only a few birds are in the region. During this time the lakes are usually ice-covered and feeding routes are along streams that do not freeze over. These are, for the most part, trout streams in the Lower Peninsula but 
winter-resident kingfishers are so few that no concern need be felt over them even though they are restricted as to the waters that they frequent. In the spring, summer, and fall, kingfishers have been observed feeding in almost all kinds of waters, both inland and along the margins of the Great Lakes. They are strikingly absent from feeder or nursery portions of stream systems, both trout and non-trout, where the marginal vegetation more or less covers the water, often forming a complete canopy from one to a few feet above it. Examples of the latter situation are the aldercovered sections of the Maple River near Pellston, Emmet County, and of the Hurricane River near Ausable Point, Alger County. Feeding birds are not seen along the turbid, lower reaches of the larger rivers, especially in the southern part of the Lower Peninsula, such as those of the Grand, Kalamazoo, Huron, and Raisin Rivers. Birds are characteristically absent from places that they ordinarily frequent along waterways when these are temporarily muddied by run-off immediately following heavy rains. They furthermore retreat from the Great Lakes shores when surf makes the water there unfishable. It may be presumed that during both of the latter conditions, recourse is had to tributaries or to other sheltered clear waters which then experience a temporary increase in the predation pressure. Trautman (1940) has described the utilization of tributaries for feeding grounds by migrants at Buckeye Lake, Ohio, when the main body of water is iced-over or turbid. On most waters the predation pressure is greatest in late summer and early fall, when, as a result of the flight of the young, the total effect is increased; but most "buffer," forage fishes have reproduced and temporarily increased their numbers by this time so that the relative effective pressure on game species by the predators may actually be less. The average increase in daily numbers of birds seen in a given locality from spring to fall may be fourfold as indicated by Trautman (1940).

\section{Food Studies}

Specimens for food study are from a wide range over the state (Figs. 1 and 2) but only a sample randomly selected from each locality is reported here since experience has shown that the numbers used are adequate and that inclusion of additional ones discloses insignificantly few new facts. The methods employed in the laboratory for stomach-content analyses, which were as precise as possible both qualitatively and quantitatively, follow those described by Salyer and Lagler (1940). We did not study regurgitated pellets such as those which formed the basis of White's (1937) work. All quantitative results, except those for lengths of fishes at capture (Table 1), are thus based on actual counts and measurements. Fragmentary remains of fish were most often found; in order to obtain information on sizes of fish eaten, it was therefore usually necessary to estimate the former whole lengths from fragments. This estimation was made by comparison of remaining parts with entire specimens or with skeletons of fish of the same kind and of known length. 
TABLE 1.-Total length (inches) of fishes eaten by the eastern belted kingfisher

\begin{tabular}{|c|c|c|c|c|}
\hline Find of fish & $\underset{\text { length }}{\text { Minimum }}$ & $\begin{array}{l}\text { Average } \\
\text { length }\end{array}$ & $\underset{\text { length }}{\text { Maximum }}$ & $\begin{array}{l}\text { Number of } \\
\text { individuals }\end{array}$ \\
\hline 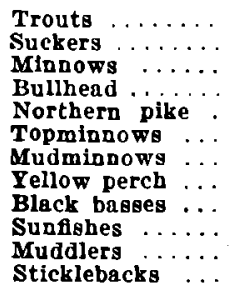 & $\begin{array}{l}1.0 \\
2.7 \\
1.5 \\
3.5 \\
4.7 \\
1.5 \\
1.5 \\
1.8 \\
1.8 \\
1.8 \\
1.7 \\
1.5\end{array}$ & $\begin{array}{l}2.3 \\
3.4 \\
2.3 \\
3.5 \\
4.7 \\
1.8 \\
3.0 \\
3.1 \\
3.0 \\
2.6 \\
2.7 \\
1.8\end{array}$ & $\begin{array}{l}7.0 \\
4.0 \\
4.0 \\
3.5 \\
4.7 \\
2.0 \\
5.0 \\
4.5 \\
5.0 \\
4.0 \\
4.0 \\
2.3\end{array}$ & $\begin{array}{r}651 \\
2 \\
6 \\
1 \\
1 \\
2 \\
6 \\
3 \\
17 \\
15 \\
14 \\
11\end{array}$ \\
\hline
\end{tabular}

Kingfishers collected by shooting, if they contain any bony fragments of food at all, usually have in them certain remains which are identifiable as to kind of organism. The stomachs of birds taken in pole traps are practically worthless in food analyses. Trapped individuals make frantic struggles to escape with the result that the food is regurgitated and lost or, if the trap is not so situated that the bird is plunged into water and drowned, food materials which remain in the stomach are very rapidly digested. Furthermore, a strategically located trap will almost invariably take a kingfisher before he has fed at the particular site.

Kingfishers at Fish Hatcheries.-It has long been known that kingfishers feed upon fishes in ponds and raceways at fish-cultural establishments. Some observations on predation and many complaints about losses to predators at such stations have been recorded. For example, in 14 kingfishers that had eaten mostly crayfishes and aquatic insects from an Ohio fish farm, Langlois (1936) found two smallmouth bass in only one bird. He suggested that this species might be more destructive than the wading birds later in the season when the bass are larger and faster and do not spend so much of their time in the shallows. De la Torre Bueno (1936) reported taking reared trout from the stomachs of hatchery kingfishers and added that this bird offers the most serious threat when the young first leave the nests and fly to rearing ponds with the adults in family groups of four to six birds. He concluded that three fingerling trout constitute a day's ration for a kingfisher. The remedy suggested as best was screening of the ponds. Hoover (1936) found 16 brook trout ranging from 1.5 to 5.5 inches in length in the stomachs of nine kingfishers taken at hatcheries in New Hampshire and concluded that the exact status of this bird is in need of study and that until such investigation is completed, reasonable control is necessary.

The fish rearing stations in Michigan, where predation by kingfishers occurs, are of two kinds; pondfish hatcheries, usually used for centrarchids, in the southern part of the Lower Peninsula; trout rearing stations mostly in the northern part of the Lower Peninsula and in the Upper Peninsula (Fig. 1). 


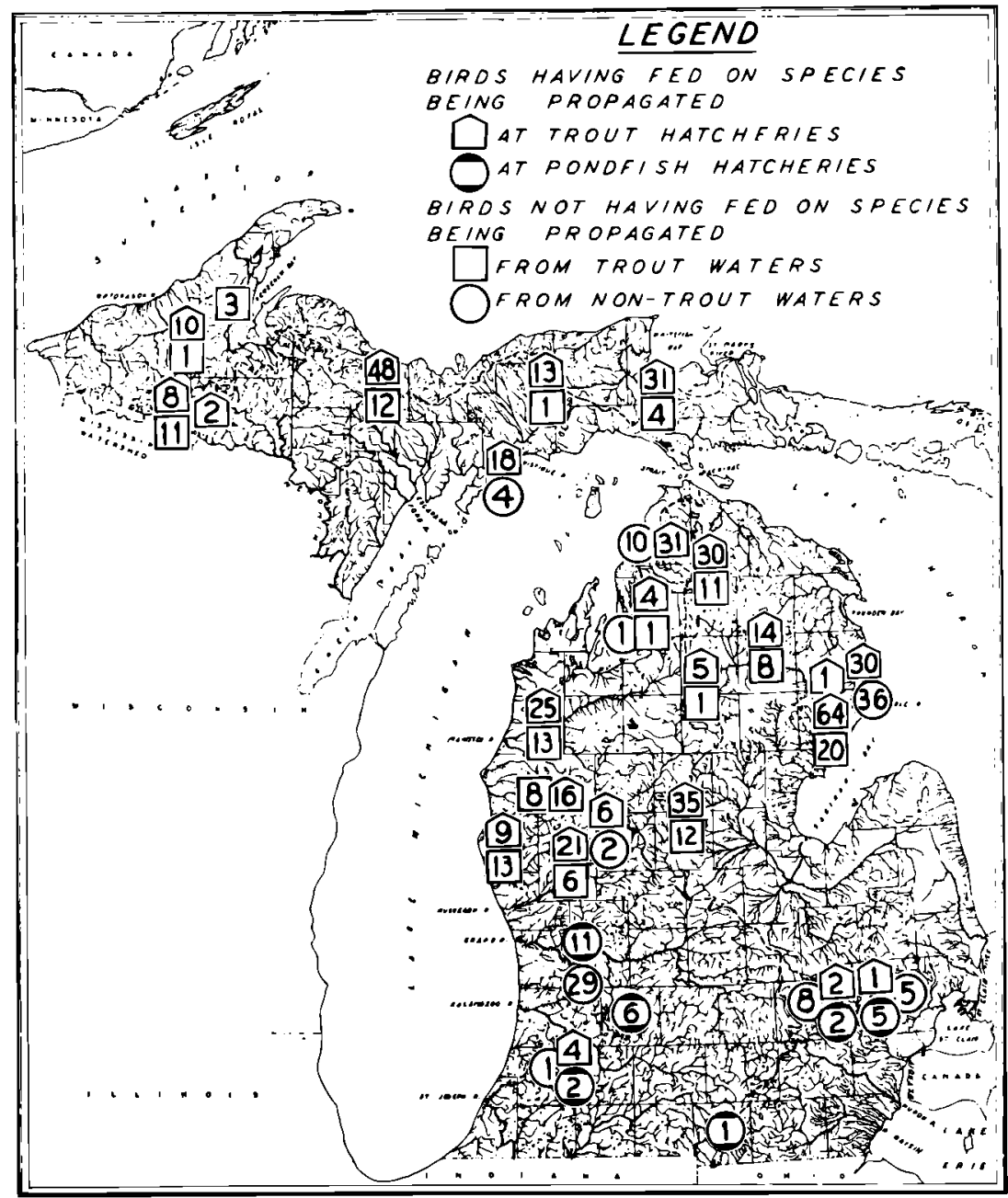

FIGURE 1.-Distribution, numbers, and classification of kingfishers collected at fishcultural stations in Michigan and studied for food.

In a general way, these two types of fish-cultural establishments represent distinct ecological entities in that the waters of pondfish stations are impoundments (often sizable: one of several near Almena, Van Buren County, is about 38 acres) whereas those of trout rearing establishments are small, stream-like raceways with moderate current and either of artificial construction near springs or sections of natural waters set off 


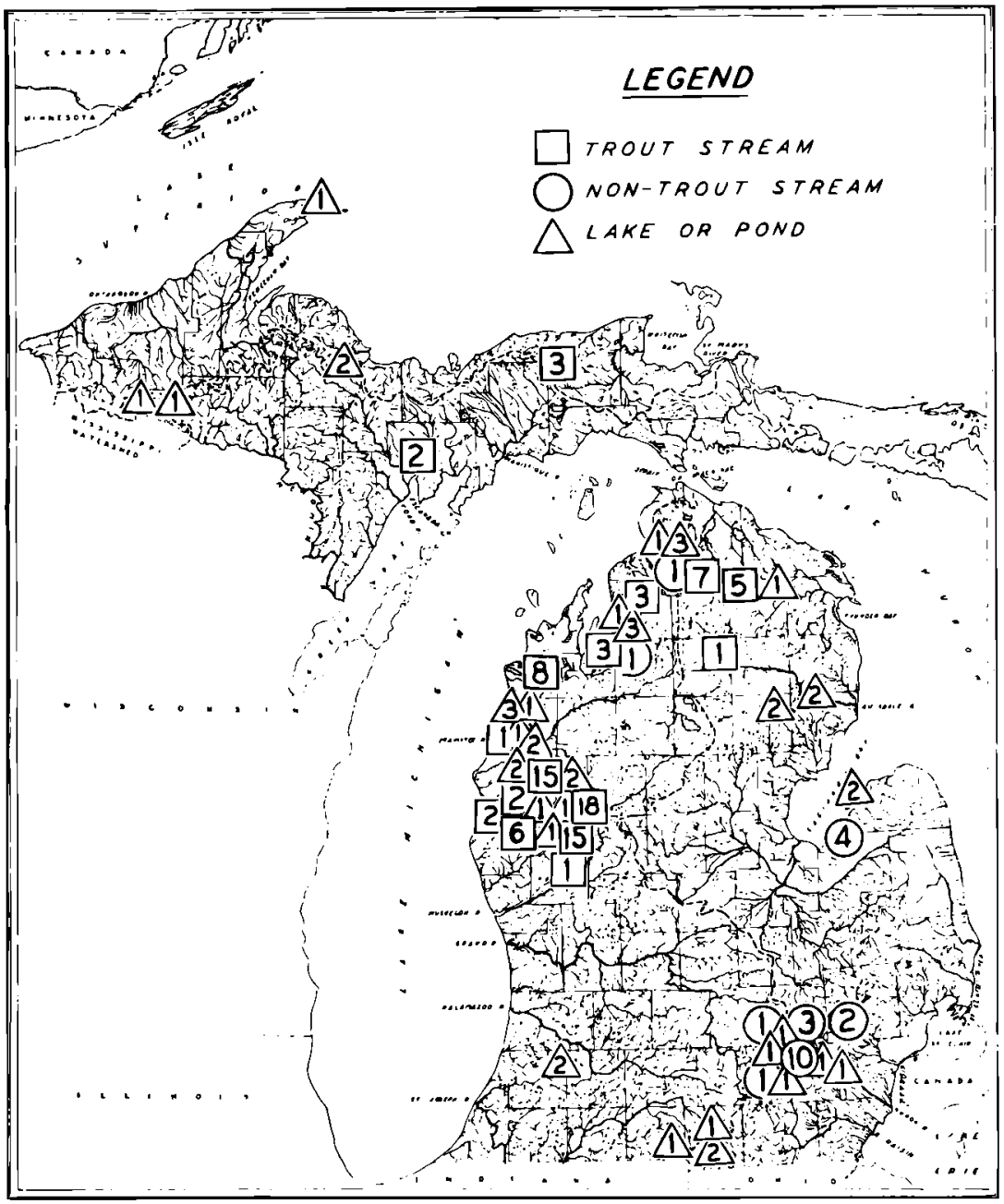

FICURE 2.-Distribution, numbers, and ecological classification of habitat for kingfishers collected on natural waters in Michigan. No birds shown in Figure 1 are repeated here.

by low dams or screens. Both types are alike, however, in containing greater concentrations of fishes of the size particularly desirable to kingfishers than exist in similar areas of natural waters. Both also appear to attract more kingfishers per unit area than do natural waters. Once an individual discovers this great and apparently inexhaustible food supply 
of an ideal size, it will come back to feed again and again so that it is almost necessary to kill the bird in order to stop its depredationsespecially if it has young nearby requiring repeated feedings and a large quantity of food.

It is common practice to kill kingfishers as a means of controlling their depredations at fish hatcheries, rearing stations, or holding ponds. It would seem that the huge take of kingfishers at the various hatchery sites in Michigan and elsewhere in the last 15 years could ultimately be responsible for a reduction in their numbers. A serious downward trend resulting from this cause could be arrested in part by a more sane and understanding handling of the bird's predatory activities. The critical period for protecting fish hatcheries and feeding stations is the month of May and the first half of June. At that time the birds are seeking territories and nesting. If they once locate the huge supply of food organisms in the hatchery ponds, of exactly the length they require, it is almost impossible to drive them away. However, if the hatchery force is alert and has guns at strategic points about the hatchery grounds during this interval, and if the bird is fired at when it first apears, even if there is no hope of hitting it, usually it will take the hint and seek a more congenial habitat. These early birds seeking territory make themselves most conspicuous by constantly uttering their shrill, rattling, challenge call.

As a means of control, it is important that no poles or other supports 4 feet or more in height be permitted in the vicinity of the ponds; they greatly facilitate activity of kingfishers since they provide excellent fishing and observation perches and thus may even attract the birds. The general use of pole traps is to be discouraged since so many song birds are taken by them. Scarecrows, flashing lights, or mirrors, and even automatic detonators are only temporarily effective since kingfishers appear to become accustomed to them and have been seen to fish from the structures supporting such devices. Screening is the most effective means of control and is most desirable esthetically but it is limited in its application to smaller bodies of water and is by no means adapted to maximum efficiency in hatchery practice (see Lagler, 1939, for description of various types of screening).

Some foresight in locating fish hatcheries and rearing stations may be valuable in reducing depredations by certain bird species including the kingfisher. Because of the great numbers of migrating kingfishers along the shores of the Great Lakes, it would be sheer folly in the future to locate any new hatchery or feeding station within 5 miles of lake shores since such a location would be directly athwart the flight lanes of the birds (and of herons and mergansers as well). The Harrisville Hatchery (Alcona County) near the shore of I.ake Huron is a case in point. Predation by kingfishers always has been heavy there and is a constant problem. This problem is even more accentuated at a private hatchery near the Lake Michigan shore. The owners of this hatchery told us that they shot and trapped more than 400 kingfishers in one spring migration. 
In the spring of 1931 there was to be seen on the grounds of this hatchery a dump of more than several bushels of kingfisher bodies. This deplorable situation can be eliminated by future planning.

Conversion of sections of headwater streams into rearing stations may invite kingfisher depredation. The opening produced in the streamside shrubbery by the creation of extended pools would tend to attract and concentrate the activities of fish-eating birds.

Trout Rearing Waters.-Of the many kingfishers studied by us from waters of this type, 428 contained food and many additional ones were empty. The stations where these specimens were obtained and the number with food from each are shown in Figure 1. The principal food of birds at these places were the salmonids being propagated (Table 2) since they comprised 80.1 percent of the total volume of food and averaged two per bird. Other prominent items eaten in decreasing numerical order were aquatic insects, forage fishes (mostly minnows, muddlers, and sticklebacks), and crayfishes.

TABLE 2.-Food of the eastern belted kingfisher on trout rearing waters

[Based on the stomach contents (747.8 cubic centimeters of food) of 428 individuals ${ }^{2}$ ]

\begin{tabular}{|c|c|c|c|}
\hline Food item & $\begin{array}{l}\text { Number of } \\
\text { individuals of } \\
\text { eacl food item }\end{array}$ & $\begin{array}{l}\text { Percentage of } \\
\text { total volume } \\
\text { of food }\end{array}$ & $\begin{array}{c}\text { Percentage } \\
\text { frequency of } \\
\text { occurrence }\end{array}$ \\
\hline $\begin{array}{l}\text { Trout } \ldots \ldots \ldots \\
\text { Other game and pan fishes } \\
\text { Forage fishes } \ldots \ldots \ldots \ldots \ldots \\
\text { Fish remains } \ldots \ldots \ldots \ldots \ldots \ldots \\
\text { Amphibians } \ldots \ldots \ldots \\
\text { Other vertebrates } \ldots \ldots \ldots \ldots \ldots \\
\text { Crayfishes } \ldots \ldots \ldots \ldots \ldots \\
\text { Insects } \ldots \ldots \ldots \ldots \ldots \ldots\end{array}$ & $\begin{array}{r}981 \\
11 \\
163 \\
\cdots 9 \\
9 \\
62 \\
347\end{array}$ & $\begin{array}{r}80.1 \\
2.1 \\
\mathbf{3 . 7} \\
2.5 \\
1.8 \\
0.5 \\
7.3 \\
3.2\end{array}$ & $\begin{array}{r}100.0 \\
1.0 \\
21.0 \\
10.3 \\
1.6 \\
0.5 \\
14.3 \\
24.1\end{array}$ \\
\hline
\end{tabular}

${ }^{1}$ Detailed identifications and enumerations of the food items in these birds follow. Trovt: Salmo gairdnerii irideus, 2 ; $s$. trutta fario, 2 ; Salmo sp., 54 ; Salvelinus $f$. fontinalis, 213 ; Salmonidae, 710, OTher GaMe aND Pa. Fishes: Percidae, 2 ; Lppomis cyanellus, $2 ; L$. gibbosus, $1 ; L$. m. macrochirus, 1 ; Centrarchldae, 5 . Foragn Fisers : Catostomus c. commersonnii, 2 ; Catostomidae, 1 ; Rhinichthys atratulus meleagris, 1 ; Semotilus a. atromaculatus, 1; Margariscus margarita nachtriebi, 1 ; Hyborhynchus notatus, 4 ; Notemigonus crysoleucas auratus, 1; Notropis cornutus, 2 ; Cyprinidae, 12 ; Umbra limi, 4 ; Fundults diaphanus menona, 1 ; Etheostomatinae, 5 ; Cottus, 99; Eucalia inconstans, 31. AMPBiBIANs : calamanders, 2 ; frogs, 7 . OTHER Vertebrates : mice, 2. Cray fisens : Cambarus virilis, $1 ; C$. immunis, 1 ; C. propinquus, 12 ; Cambarus sp., 48. Insecrs : Orthoptera, 1 ; Baetinae, 27 ; Ephemeridae, 10; Libellula, 1 ; Anax junius, 1 ; Aeschna umbrosa, 2; Zygoptera, 4; Anlsoptera nymphs, 17; Odonata, 5 ; Plecopters, 1 ; Lethocerus americantes, 1 ; Belostomatidae, 2 ; Aphidae, 1 ; Helicopsyche, 4 ; Trichoptera. $80 ;$ Dytiscus, 1 ; Dytiscidae, 2 ; Carabldae, 1 ; Staphylinidae, 3 ; Cbrysomelidae, 1 ; Coleoptera. 29; Chironomidae, 99; Stratiomyldae, 1; Rhaglonidae, 1 ; Diptera, 4 ; Form. Icldae, 1 : Hymenoptera, 8 ; unidentified, 42.

Some of the food appearing in the stomachs of these birds obviously had been eaten prior to their descent upon the hatchery waters. This view is substantiated by the considerable number of individuals (131) taken at these stations but not containing representatives of the species being propagated (Fig. 1). Such birds, it seems, were killed before they had 
opportunity to prey on fishes in the rearing enclosures and for this reason they are discussed with kingfishers from natural trout streams (Table 4). It is likewise possible that some of the kingfishers collected at the hatcheries and containing trout may have obtained those fish from the adjacent natural waters. Since we had no way of detecting these trout from natural waters for most birds and in view of the much lower incidence of trout in the food of this bird on natural trout waters (Table 4) we believe the inherent error to be insignificant. Furthermore, trout hatcheries using spring water, such as the one near Almena, Van Buren County, or that at Oden, Emmet County, have practically no trout streams nearby and the birds entering would therefore not be likely to contain such fishes.

Pondfish Rearing Waters.-Twenty-seven kingfishers are available for recording the food habits of this bird on such waters (Table 3 ). Several more that were opened were empty and still others contained none of the species being propagated. The latter birds taken at pondfish hatcheries are considered to have flown in from adjacent non-trout waters and are discussed with kingfishers from non-trout streams (Table 5).

TABLE 3.-Food of the eastern belted kingfisher on pondfish rearing waters [Based on the stomach contents (59.1 cubic centimeters of food) of 27 individuals ${ }^{1}$ ]

\begin{tabular}{|c|c|c|c|}
\hline Food item & $\begin{array}{l}\text { Number of } \\
\text { individuals of } \\
\text { each food item }\end{array}$ & $\begin{array}{l}\text { Percentage of } \\
\text { total volume } \\
\text { of food }\end{array}$ & $\begin{array}{c}\text { Percentage } \\
\text { frequency of } \\
\text { occurrence }\end{array}$ \\
\hline $\begin{array}{l}\text { Pan fishes } \ldots \ldots \ldots \ldots \ldots \\
\text { Forage fishes } \ldots \ldots \ldots \ldots \ldots \\
\text { Fish reinains } \ldots \ldots \ldots \ldots \ldots \\
\text { Crayfishes } \ldots \ldots \ldots \ldots \ldots \\
\text { Insects } \ldots \ldots \ldots \ldots\end{array}$ & $\begin{array}{r}52 \\
44 \\
6 \\
14\end{array}$ & $\begin{array}{r}85.8 \\
8.0 \\
0.8 \\
2.7 \\
2.7\end{array}$ & $\begin{array}{r}100.0 \\
40.7 \\
25.9 \\
18.5 \\
29.6\end{array}$ \\
\hline
\end{tabular}

Detailed identifications and enumerations of the food items in these birds follow. GAME AND PAN Fishes: Micropterus salmoides, 1 ; Micropterus d. dolomieu, 9 ; black basses, 26 ; Lepomis gibbosus, 1 ; $\mathrm{L} . \mathrm{m}$. macrochivus, 7 ; Lepominae, 2 ; Centrarchidae, 6 . Forage Fishes: Catostomidae, 2 ; Notemigonus crysoleucas auratus, 1 ; Notropis cornutus, 4; Cyprinidae, 11 ; Umbra limi, 1 ; Cottus sp., 8; Eucalia inconstans, 17 . CraYFIsHes : Cambarus virilis, 1; C. immunis, 2; Cambarws sp., 3. Ixsects : Odonata, 4; Fiphemeridae, 1 ; Coleoptera, 1 ; Chironomidae, 5 ; unidentified, 4.

The kingfisher at warm-water fish rearing establishments shows a striking resemblance (Table 3 ) in food habits to those from trout cultural stations (Table 2). The birds average about two per individual of the species being propagated and these fishes compose 85.8 percent of the total volume of food. The remainder of the organisms eaten are again principally minnows, crayfishes, and insects.

Kingfishers on Natural Waters. - The food habits of the kingfisher on natural waters have been summarizd by Bent (1940) with the indication that juveniles and adults feed on the most available aquatic organisms of suitable size. This general conclusion is attested by the following data from extensive analyses on record in the U. S. Fish and Wildlife Service (Howell, 1932). Perch, mainly Perca flavescens, were found in 16 
stomachs; catfishes in 15; flounders in 13; sunfishes in 9; and carp in 3. Non-edible fishes were identified in 82 of 162 stomachs; small minnows were in 57 , sculpins were in 8 , and sticklebacks, killifishes, and menhaden made up the remainder. Crayfishes were present in 39 individuals, comprising about 16 percent of the food, frogs formed about 5 percent, and insects, 4 percent. Fishes in all composed about 75 percent of the food of the bird.

In an analysis of the food of kingfishers in various habitats progressively further upstream in the Margaree and Apple River systems of Nova Scotia, White (1937) found that in the lower reaches many species of fish are taken, but further upriver the number of kinds becomes less until only salmon and brook trout or trout alone constitute the food. In a more restricted region, though one possessing a diverse fauna, namely in the vicinity of Ithaca, New York, breadth of food habit is again indicated (Gould, MS). ${ }^{3}$

We have new data on the food of the kingfisher on trout streams, nontrout streams, and lakes (Fig. 2). Stomachs of this bird on natural waters are from two principal sources. One group is from bona fide natural situations and was collected over most of the state in order to obtain a general picture of the kinds and amounts of food eaten. The other represents a more or less chance accumulation of birds resulting from control operations at fish hatcheries and rearing stations (Fig. 1). Many birds shot or pole-trapped at fish-cultural stations contained none of the species being cultured and, as indicated, have not been previously reported upon in this paper. Data on these birds are presented separately in the tables for birds from trout streams (Table 4 ) and from non-trout streams (Table 5). Obviously these specimens taken at hatcheries offer significant information on predation at fish-propagation establishments but they appear to contribute more to an understanding of the food habits on natural waters. That such kingfishers represent individuals taken prior to feeding in the hatchery waters is substantiated by their stomach contents. The fact that these specimens were selected on the basis of the absence of the species being reared from their stomach contents precludes their being used in any way to indicate nonexistence of predation in natural waters on the fish species primarily concerned. They do afford, however, an amplification of the list of other organisms preyed upon by king-

\footnotetext{
A A condensation of Gould's original records of analyses, made by the U. S. Fish and willlife Service, is reproduced here with the permission of Harrison F. Jewis, in whose custody the manuscript lies, since it is likely that it will remain unpublished for some time. Tlie name of each food item and the number of times the item occurred in the 25 stomachs examined are given. For the fishes, the list is in decreasing order of number of individuals of each item. Fish : Pomolobus sp., 5; Salmo trutta fario, 9; Catostomus c. commersonnii, 14: Cyprinidae, 12 : Cuprinus curpio, 1 : Leucosomus cor poralis, 1 ; Semotilus a. atromaculatus, 15; Exoglosstm maxillingua, 2 ; Rhinichthys a. atratulus, 7 ; Hybopsis sp., 2 ; Hybognathus sp.. $1 ;$ Notropis sp.. $4 ;$ Notropis cornutus, 9 ; Ameiurtes sp., 4: Fundulis diaphanus, 1; Pcrca flavescens, 2 : Bolcosoma nigrum, 4; Micropterus salmoides, 5; Lepomin sp., 2 ; Iepomis gibbosus, 4 ; Cottus sp., 1 . Fnocs: Rana sp., 6. RePtiles : Snakes, 2, Issfcts : Anisoptera, 1 : Aeschnidae. $1: I_{y / d r o u s}$ triangularis, 1 ; Berosus sp., 1 ; Haliplus sp., 1; Clateridae, 1 : Chrysomelidae. 1 ; Cur. culionidae, 1 ; Camponotus herculeanus, 1 ; Hymenoptera, 1. Carstacraxs: Cambarus sp., 13 .
} 
fishers and corroborate the evidence afforded by the bona fide samples from natural waters so well that additional sacrifice of birds for food study was unneccessary.

Trout Streams.-Trout streams of a wide variety of sizes and kinds are found in Michigan. As has been indicated, fishes in all except the smallest of them are exposed to predation by kingfishers. That trout are eaten cannot be denied; our findings (Table 4) show an incidence of approximately one for every two birds. Almost two-thirds of the bulk of the food and most of the food organisms by number, however, are made up of forage fishes and crayfishes. It is suspected that the vulnerability of forage fishes varies greatly from stream to stream. Furthermore, it is generally conceded that such fishes are less wary than trout and that they are most abundant in the open, sunlit parts of the streams (Hankinson, 1923) which kingfishers frequent whereas the trout are in

TABLE 4.-Food of the eastern belted kingfisher on trout streams

[Based on the stomach contents (266.7 cubic centimeters of food) of 92 individuals collected on natural trout streams ${ }^{1}$ and on the stomach contents $(186.1$ cubic centimeters of food) of $\mathbf{1 3 1}$ Individuals taken at fish hatcheries but representing food habits on natural trout waters ${ }^{2}$ ]

\begin{tabular}{|c|c|c|c|c|c|c|}
\hline \multirow{2}{*}{ Food item } & \multicolumn{2}{|c|}{$\begin{array}{l}\text { Number of individ- } \\
\text { uals of each food } \\
\text { item }\end{array}$} & \multicolumn{2}{|c|}{$\begin{array}{l}\text { Percentage of total } \\
\text { volume of food }\end{array}$} & \multicolumn{2}{|c|}{$\begin{array}{c}\text { Percentage frequency } \\
\text { of occurrence }\end{array}$} \\
\hline & $\begin{array}{c}\text { From } \\
\text { natural } \\
\text { trout } \\
\text { streams }\end{array}$ & $\begin{array}{l}\text { From } \\
\text { hatch. } \\
\text { eries }\end{array}$ & $\begin{array}{c}\text { From } \\
\text { natural } \\
\text { trout } \\
\text { streams }\end{array}$ & $\begin{array}{l}\text { From } \\
\text { batch- } \\
\text { eries }\end{array}$ & $\begin{array}{c}\text { From } \\
\text { natural } \\
\text { trout } \\
\text { streams }\end{array}$ & $\begin{array}{l}\text { From } \\
\text { hatch- } \\
\text { eries }\end{array}$ \\
\hline 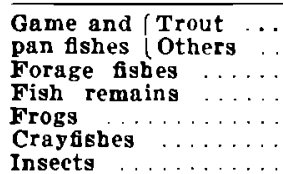 & $\begin{array}{r}40 \\
14 \\
68 \\
\cdot 1 \\
58 \\
8\end{array}$ & $\begin{array}{r}14 \\
122 \\
12 \\
56 \\
91\end{array}$ & $\begin{array}{c}29.8 \\
13.0 \\
15.0 \\
0.9 \\
\text { Trace } \\
40.7 \\
0.6\end{array}$ & $\begin{array}{r}4.4 \\
15.4 \\
0.9 \\
13.2 \\
50.5 \\
15.5\end{array}$ & \begin{tabular}{r|}
35.9 \\
13.0 \\
35.9 \\
14.1 \\
1.1 \\
53.3 \\
8.7
\end{tabular} & $\begin{array}{r}\mathbf{6 . 9} \\
\mathbf{3 9 . 7} \\
9.2 \\
\mathbf{7 . 6} \\
\mathbf{3 9 . 7} \\
\mathbf{3 4 . 4}\end{array}$ \\
\hline
\end{tabular}

1 Detailed identifications and enumerations of the food items in blrds collected on natural trout streams follow. Game and PAN Frsaes: Salmo gairdnerii irideis, $6 ; S$. trutta fario, 1 ; Salmo sp., 3; Salvelinus f. fontinalis, 5 ; Salmonidae, 25 ; Ameluridae, 1 ; Esox lucius, 1 ; Perca flavescens, 5; Lepomis m. maciochirus, 2 ; Centrarchldae, 5. ForaGn Fisnes: Moxostoma sp., 1; Catostomidee, 2 ; Cyprinidae, 6; Umbra limi, 1; Etheostomatinae, 5; Cottus op., 22 ; Eucalia inconstans, 29. Frogs: Rana sp., 1. Crayeisges: Cambarus virilis, 14 ; C. propinquus, 20 ; Cambarus sp., 24. INsects: Anlsoptera, 3 ; Stratiomyidae, 1 ; unidentified, 4.

2 Detailed ddentifleation and enumerations of the food items in birds collected at hatcheries but representing food habits on natural trout waters follow. GaME AND PAN Fishes : Perca flavescens, 2 ; Micropterus d. dolomieu, 1 ; Lepomis cyanellus, 4 ; Centrarchidae, 7. Forage Fishes: Catostomus c. commersonnii, 2 ; Catostomidae, 3 : Rhinichthys atratulus meleagris, 1 ; Semotilus a. atromaculatus, 2 ; Hyborhynchus notatus, 9 ; Notropis cornutus, 5: Cyprinidac, 24; Umbra limi, 1; Fundulus diaphanus menona, 7 ; Etheostomatinae, 5 ; Cottus cognatus, 1 ; Cottus sp., 34 ; Eucalia inconstans, 26. Frogs : Rana sp., 12. Crayrishes : Cambartus virilis, $3 ; C$. propinguus, $24 ; C$. immunis, $6 ; C$. diogenes, 1 ; Canbarus sp., 22. INsects : Orthoptera, 1; Anax junius, 2 ; Epiaeschna sp., 1 ; Anisoptera nymphs, 19 : Odonata, 1 ; Lethocerts americanus, 1 ; Lethocerus sp., 2; Belost omatidae, 2 ; Cicadellidae, 1 ; Aphidae, 1 ; Ephemeridae nymph, 1 ; Dytiscus $\boldsymbol{H a r}$ risii, 2; Dytiscus dattricus, 1; Dytiscus sp., 1; Dytiscidae, 15; Gyrinidae, 1; Haliplus sp., 1 ; Coleoptera, 1 ; Trichoptera larvae, 27 ; Diptera eggs, 6 ; unldentified, 2 . One water mite, Acarina, was also found and is included in this category for convenience. 
TABLE 5.-Food of the eastern belted kingfisher on non-trout streams

[Based on the stomach contents ( 67.7 cuble centimeters of food) of 22 individuals collected on netural waters ${ }^{1}$ and on the stomech contents (157.8 cubic centimeters of food) of 95 individuals taken at fish hatcheries but representing food hablts on natural waterg $\left.{ }^{2}\right]$

\begin{tabular}{|c|c|c|c|c|c|c|}
\hline \multirow{2}{*}{ Food item } & \multicolumn{2}{|c|}{$\begin{array}{l}\text { Number of individ- } \\
\text { uals of each food } \\
\text { item }\end{array}$} & \multicolumn{2}{|c|}{$\begin{array}{l}\text { Percentage of total } \\
\text { rolume of food }\end{array}$} & \multicolumn{2}{|c|}{$\begin{array}{l}\text { Percentage frequency } \\
\text { of occurrence }\end{array}$} \\
\hline & $\begin{array}{c}\text { From } \\
\text { natural } \\
\text { non-trout } \\
\text { streams }\end{array}$ & $\begin{array}{l}\text { From } \\
\text { hatch- } \\
\text { eries }\end{array}$ & $\begin{array}{c}\text { From } \\
\text { natural } \\
\text { non-trout } \\
\text { streams }\end{array}$ & $\begin{array}{l}\text { From } \\
\text { hatch- } \\
\text { eries }\end{array}$ & $\begin{array}{c}\text { Frow } \\
\text { natural } \\
\text { non-trout } \\
\text { streams }\end{array}$ & $\begin{array}{l}\text { From } \\
\text { hatch- } \\
\text { eries }\end{array}$ \\
\hline $\begin{array}{l}\text { Game and pan fishes } \\
\text { Forage fishes } \ldots \ldots \ldots \\
\text { Other fishes } \ldots \ldots \ldots \\
\text { Fish remaing } \ldots \ldots \\
\text { Frogs } \ldots \ldots \\
\text { Other vertebrates } \ldots \\
\text { Crayfishes } \ldots \ldots \ldots \ldots \\
\text { Insects } \ldots \ldots \ldots \ldots \ldots\end{array}$ & $\begin{array}{r}5 \\
12 \\
1 \\
\cdots \\
18 \\
18 \\
4\end{array}$ & $\begin{array}{r}\mathbf{7} \\
\mathbf{8 9} \\
\cdots \\
-6 \\
\mathbf{2} \\
\mathbf{3 2} \\
\mathbf{5 7}\end{array}$ & $\begin{array}{r}10.5 \\
31.3 \\
16.2 \\
0.1 \\
\cdots \\
39.6 \\
2.2\end{array}$ & $\begin{array}{r}3.4 \\
17.1 \\
0.8 \\
0.8 \\
9.7 \\
1.3 \\
18.8 \\
49.0\end{array}$ & $\begin{array}{r}22.7 \\
40.9 \\
4.5 \\
13.6 \\
\cdots \\
59.1 \\
18.2\end{array}$ & $\begin{array}{r}6.3 \\
35.8 \\
76.3 \\
2.1 \\
2.1 \\
27.4 \\
42.1\end{array}$ \\
\hline
\end{tabular}

1 Detailed Identifications and enumerations of the food items in these birds follow. Game and Pan Fisues: Perca flavescens, 2 ; Centrarchidae, 3. Foragr Fismes: Catostomidae, 1; Hyborhynchus notatus, 3; Notemigonus crysoleucas auratus, 1; Notropis atherinoides, $2 ; N$. hudsonius, 1 : Cyprinidae, $2 ;$ Umbra limi, 1 ; Cottus sp., 1. ОтвER Fishes: Esox vermiculatus, 1 . Crayeishes : Cambarus propinguts, 14 ; Cambarus sp., 4. Insects : Belostomatidae, 2 ; Ephemeridae, 2.

2 Detailed Identifications and enumerations of the food items in birds collected at hatch. eries but representing food labits on natural non-trout waters follow. Game and PAN Fishes: Perca flavescens, 3 ; Lepomis cyanellus, $2 ; L$. m. macrochirus, 2. ForAGB Fisues : Catostomus C. Commersonnii, 2 ; Catostomidae, 1 ; Hyborhynchus notatus, 12 ; Notropis cornutus, 50; Cyprinidae, 10: Umbra limi, 4; Fundulus diaphanus menona, 1 ; Etheostomatinae, 5 ; Cottus b. bairdii, 2 ; Cottus sp., 2. Frogs: Rana sp., 6. OTBEr VerTEBrates : Turtle egg, 1 . Crayfshes: Cambarus virilis, $6 ; C$. propinquus, 5 ; C. immunis, 7 ; Cambarus sp., 15. Insects : Anax junius, 4; Aeschnidae, 2 ; Anispotera nymphe, 11 : Lethocerus americanus, 8; Lethocerus sp., 3; Benacus sp., 1; Dytiscus harrisii, 1 : Dytiscus sp., 13; Acilins sp., 2; Dytiscidae, 2; Coleoptera, 1 ; Chironomldae larvae, 2 ; unidentified, 1 .

the darker, deeper, and more sheitered portions. Experiments on the effects of predation by White (1937) led to the conclusion that competition and cannibalism were a greater menace to young trout than attacks by birds including kingfishers and members of the heron family.

A part of the food is composed of game and pan fishes other than trout, which have no recognizable value for sport in these situations. At least some of these fishes are strays from lakes situated in the drainage systems of the streams and are not regular inhabitants of Michigan trout waters. Some that are eaten, for example the predacious northern pike (Esox lucius), are liabilities in trout streams as indicated by Hankinson (1923). Crayfishes, forage fishes, and insects are utilized in common by trout (Metzelaar, 1929; Needham, 1938; Lagler and Lagler, 1944) and by kingfishers. It has further been suggested (Hankinson, 1923) that two of the forage species (Semotilus a. atromaculatus and Notropis cornutus) eaten by kingfishers may be incompatible with native trout since they offer competition for food.

The interrelationships of predator and prey are here, as always, very 
complicated, and the exact status of the kingfisher in relation to trout production in natural waters is therefore undecipherable on the basis of the data thus far obtained.

Non-trout Streams. - The considerable importance of crayfishes as seen in the food of kingfishers on trout streams (Table 4) is also somewhat evident in that of specimens from running waters that are not inhabited by trout (Table 5). To some extent the large numbers of crayfish may be the result of the numerical dominance of young birds in our collections. Insects are more important in birds collected at hatcheries, but not containing hatchery fish, than in those from natural waters. Forage fishes again are the numerically dominant food organisms and, among the fish, they exceed the others by far in both numbers and bulk. 'This preponderance of forage fish, of course, reflects the leading numerical abundance which is usual for forage species in fish populations in streams of this kind. Vertebrates as a whole appear to be of greater significance to the kingfisher as food on these waters than are the arthropods.

Lakes.-A difference in the food habits of kingfishers in standing waters from those in running waters is suggested by our data (Table 6). Crayfishes are not a food item of major importance to this bird in lacustrine situations. This fact would seem to indicate a lesser abundance of these decapods per unit area of fishable lentic waters than lotic ones, or it might suggest a greater proportionate abundance of forage fishes to crayfishes in the former since much of the numerical and volumetric loss for crayfishes has been gained by forage fishes which are by far the most important item of sustenance. Insects are second by volume in apparent importance but game and pan fishes are probably of greater actual significance for their volume would exceed that of the insects if both were

TABLE 6.-Food of the eastern belted kingfisher on lakes

[Based on the stomach contents (92.1 cubic centimeters of food) of 45 indiriduals ${ }^{1}$ ]

\begin{tabular}{|c|c|c|c|}
\hline Food item & $\begin{array}{l}\text { Number of } \\
\text { individuals of } \\
\text { each food item }\end{array}$ & $\begin{array}{l}\text { Percentage of } \\
\text { total volume } \\
\text { of food }\end{array}$ & $\begin{array}{l}\text { Percentage } \\
\text { frequency of } \\
\text { occurrence }\end{array}$ \\
\hline 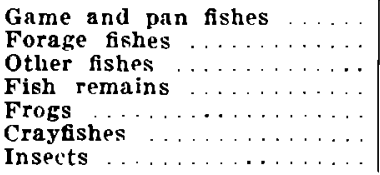 & $\begin{array}{r}29 \\
78 \\
2 \\
-6 \\
18 \\
15\end{array}$ & $\begin{array}{r}17.5 \\
49.1 \\
2.0 \\
0.9 \\
2.3 \\
7.4 \\
21.0\end{array}$ & \begin{tabular}{r|}
20.0 \\
51.1 \\
4.4 \\
22.2 \\
13.3 \\
26.7 \\
37.8
\end{tabular} \\
\hline
\end{tabular}

${ }^{1}$ Detailed identifications and enumerntions of the food items in these birds follow. Game and Pan Fishes: Perca flavescens, 17; Micropterus d. dolomieu, 1; Lepomis cyanelliks, 1 ; L. gibbosus, 1 : L. m. marrochirus, 3: Centrarchidae, 6. Fonagr Fishes : Catostomidae. 1 C Cyprinus carpio, 1 : Hyborhymchus notatus, 49 : Notemigonus crysoleucas auratus, 1 ; Notropis hutsonius, 1 ; Cyprinidae, 7 ; Umbra limi, 1: Percina caprodes semifasciata, 1 ; Ftheostomatinae. 7 : Labidcsthes s. sicculus, 7 ; Cottus sp., 1 ; Eucalia inconstans, 1. Othre Fisnms: Esocidae, 1: Lota lotr maculosa, 1. Frocs: Rana sp., 6. ChaYfishes: Cambartus virilis, 3 ; C. immunis, 1 : C. propinquts, 3 : Cambarus sp., 11. Insfers: Anax junius nymph, 1 ; Anisoptera, 3 ; Belostomatidae, 1 ; Dytiscidae, 2 ; unidentified, 8 . 
restored to their original bulk on ingestion. The number of specimens of kingfishers on which these observations are based is, however, small.

\section{Present Status of the Kingfisher Problem}

Several comments have been published on the relationships between fish-eating birds, including the kingfisher, and fish. Vladykov (1943) alone has attempted to present in one paper an unbiased summary of the views of the several authors and has listed the three categories of interpreters of the role of these birds. (1) ultra-preservationists; (2) exponents of stringent control; (3) those who take the middle course. In general one would find over-enthusiastic laymen or those directly dependent upon them for income in the first two categories, and, those who try to apply a more scientific method in arriving at their conclusions in the third. Obviously, then, our data constitute ammunition for any of these groups. Ultra-preservationists will emphasize the broad diet of the kingfisher, as here attested, and will continue against control. Fish-culturists and ardent anglers will regard as of primary importance the feeding of the bird on populations of their selected species. Neither group will, however, be fully able to justify its case on the basis of what is now known. Staggering and damning estimates of the total numbers of fish consumed may be made (e.g., Sinker, 1883; Sullivan, 1912; White, 1936), but unless these estimates are interpreted in light of existing populations of both predators and prey in specific areas, they are obviously invalid and worse than misleading.

The conclusions that we draw from our study are very limited and not at all trenchant. Because of its predatory potential of more than 50 small fingerlings per day (determined experimentally by White, 1936) and the established fact that on fish rearing waters it consumes quantities of the fishes being propogated, the kingfisher is incompatible with fishcultural practices of the present time. In recognition of this difficulty, may not organizations fostering the ultra-preservationist attitude be expected to share in the extra cost of protecting fishes at hatcheries by nonlethal means rather than by shotgun or pole-trap? On natural waters, with the possible exception of spawning areas or of nursery grounds such as headwater trout streams, we conclude that the kingfisher is relatively innocuous as a fish predator. Such prey in the form of preferred fish species or their food organisms which kingfishers consume on most natural waters can easily be considered as a small tax, gladly given, for the esthetic virtues of this bird.

That there are possible benefits as well as undesirable effects of predation has often been stated (e.g., Lagler, 1944). A detailed discussion of this matter does not appear to be desirable here.

\section{Literature Cited}

Bent, A. C.

1940. Life histories of North American cuckoos, goatsuckers, hummingbirds and their allies. Bull. U. S. Nat. Mus., No. 176, viii +506 pp. 
de la Torre Bueno, J. R., Jr.

1936. Some observations on the kingfisher. Fish Culture (N. Y. Cons. Dept.), Vol. 2, No. 9, pp. 11-14.

HANKINSON, T. L.

1923. The habitat of the brook trout in Michigan. Pap. Mich. Acad. Sci., Arts, and Lett., Vol. 2, 1922, pp. 197-205.

Hoover, Earl E.

1936. Fish-eating birds. Prog. Fish-Cult., No. 21, pp. 21-22.

HoweLI, A. H.

1932. Florida bird life. Dept. Game and Fresh Water Fish, Tallahassee, Fla, xxiv +579 pp.

LAGLER, KaRL F.

1939. The control of fish predators at hacheries and rearing stations. Jour. Wildlife Man., Vol. 3, No. 3, pp. 169-179.

1943. Neglected sources of data. Wilson Bull., Vol. 55, No. 2, p. 132.

1944. Problems of competition and predation. Trans. Ninth N. Am. Wildlife Conf., pp. 212-219.

Lagler, Karl F, and Mary Jane Lagler

1944. Natural enemies of crayfishes in Michigan. Pap. Mich. Acad. Sci., Arts, and Lett., Vol. 29, (1943), pp. 293-303.

LangLoIS, T. H.

1936. A study of the small-mouth bass, Micropterus dolomieu (Lacépède) in rearing ponds in Ohio. Ohio Biol. Surv. Bull. No. 33, Ohio State Univ. Stud., Vol. 6, No. 4, pp. $189-225$.

Metzelaar, Jan

1929. The food of the trout in Michigan. Trans. Am. Fish. Soc., Vol. 59, pp. 146152.

NeEdham, Paul R.

1938. Trout streams. Comstock Publishing Company, Inc., Ithaca, N. Y., $x+$ $233 \mathrm{pp}$.

Salyer, J. Clark, II, and Karl F. Lagler

1940. The food and habits of the American merganser during winter in Michigan, considered in relation to fish management. Jour. Wildlife Man., Vol. 4, No. 2, pp. 186-219.

SIN KER, WOODEN

1883. About kingfishers. Forest and Stream, Vol. 21, No. 10, pp. 188-189.

Sullivan, R. H.

1912. Economic value of bird life. Agri. Educ. (Kansas State Agri. Coll.), Vol 7, pp. 1-4\%.

Trautman, Milton B.

1940. The birds of Buckeye Lake, Ohio. Univ. Mich. Mus. Zool., Misc. Publ. No. 44, $466 \mathrm{pp}$.

VIADYKOV, VADIM D.

1943. Relation between fish and fish-eating birds. Can. Field Nat., Vol. 57, pp. 124-132. 
White, H. C.

1936. The food of kingfishers and mergansers on the Margaree River, Nova Scotia. Jour. Biol. Bd. Can., Vol. 2, No. 3, pp. 299-309.

1937. Local feeding of kingfishers and mergansers. Jour. Biol. Bd. Can., Vol. 3, No. 4, pp. 323-338.

1939. Change in gastric digestion of kingfishers with development. Am. Nat., Vol. 73, No. 745, pp. 188-190. 